\title{
Editorial
}

\section{Why there are and will be less deaths in India due to COVID-19: an insight}

\author{
Chincholikar Sanjeev Vasantrao*
}

Department of Community Medicine, MIMER Medical College, Telegaon Dabhade, Pune, Maharashtra, India

Received: 08 June 2020

Revised: 13 July 2020

Accepted: 14 July 2020

\section{*Correspondence: \\ Dr. Chincholikar Sanjeev Vasantrao, \\ E-mail: aruna@mitmimer.com}

Copyright: (c) the author(s), publisher and licensee Medip Academy. This is an open-access article distributed under the terms of the Creative Commons Attribution Non-Commercial License, which permits unrestricted non-commercial use, distribution, and reproduction in any medium, provided the original work is properly cited.

Coronavirus disease (COVID-19) is an infectious disease caused by a newly discovered coronavirus. Most people infected with the COVID-19 virus will experience mild to moderate respiratory illness and recover without requiring special treatment. It has been declared a pandemic by the World Health Organization which exhibited human-tohuman transmissibility and spread rapidly across countries. ${ }^{1}$ Older people, and those with underlying medical problems like cardiovascular disease, diabetes, chronic respiratory disease, and cancer are more likely to develop serious illness. Climate, with temperature, humidity, Bacillus Calmette-Guérin (BCG) vaccination, immune status of persons, elderly people, uncontrolled co morbid conditions like heart diseases, diabetes mellitus, hypertension, kidney diseases seems to play an important role in spread and severity of corona virus infection. ${ }^{1}$ As reported from MOHFW website, the COVID-19 deaths are more in above 60 years of age with comorbidities cardiovascular disease, diabetes, chronic respiratory disease, and cancer. ${ }^{2}$

One of the studies did mention the importance of weather variables in the transmission of infectious diseases. ${ }^{1} \mathrm{~A}$ sharp change of ambient temperature was associated with increased risk of SARS. ${ }^{3,4}$ Influenza transmission is enhanced in the presence of cold and dry air. In northern Europe, low temperature and low ultraviolet (UV) indexes were correlated with peaks of influenza virus activity during 2010-2018. COVID-19 transmission may decrease or even disappear when the temperature and UV radiation increase in the summer. ${ }^{5}$
High temperature and high relative humidity significantly reduce the transmission of COVID-19. An increase of just one degree Celsius and $1 \%$ relative humidity increase substantially lower the virus's transmission. The study is peer-reviewed, that examines the effect of weather on the spread of the SARS-Cov-2 virus, which causes the COVID-19 illness. $^{6}$

Another explanation is that hotter temperatures in India may slow the virus. There is some evidence consistent with this theory. Countries with latitudes between 30-50 degrees above or below the equator, and average temperatures between 5 and 11 degrees Celsius have, thus far, borne a higher burden from COVID. Some preliminary research has suggested that India may face higher transmission rates during the monsoon, which is India's flu season. Humidity may also play a role; various studies have found varying results on its importance as a factor. A study at Harvard has suggested that COVID-19 may not go away in warm weather as colds do, because significant parts of the population are vulnerable to the virus. The weather alone is insufficient to protect India. An unpublished analysis comparing the weather in 500 locations around the world where there have been COVID-19 cases seems to suggest a link between the spread of the virus and temperature, wind speed and relative humidity. In one of the unpublished studies it has been shown that higher temperatures are linked to lower incidence of COVID-19, 
Table 1: COVID-19 status in select countries as on 08 June 2020.

\begin{tabular}{|cllll|}
\hline S. no. & Country & COVID-19 positive cases & Recovered & Deaths \\
\hline 1. & USA & $2,007,696$ & 761,723 & 112,472 \\
\hline 2. & Brazil & 691,962 & 302,084 & 37,312 \\
\hline 3. & Russia & 476,658 & 230,688 & 5,971 \\
\hline 4. & Spain & 288,630 & 7,015 & 27,136 \\
\hline $\mathbf{5 .}$ & UK & 286,194 & 135 & 40,542 \\
\hline $\mathbf{6 .}$ & India & 258,090 & 124,095 & 7,207 \\
\hline $\mathbf{7 .}$ & Italy & 234,998 & 165,837 & 33,899 \\
\hline $\mathbf{8 .}$ & Peru & 196,515 & 86,219 & 5,465 \\
\hline 9. & Germany & 185,869 & 169,600 & 8,776 \\
\hline
\end{tabular}

Source: Coronatracker.com

Research on other enveloped viruses suggests that this oily coat makes the viruses more susceptible to heat than those that do not have one. In colder conditions, the oily coat hardens into a rubber-like state, much like fat from cooked meat will harden as it cools, to protect the virus for longer when it is outside the body. Most enveloped viruses tend to show strong seasonality as a result of this. Why does India have so few COVID-19 cases and deaths? High temperature and high humidity reduce the transmission of COVID-19 according to Jingyuan Wang. ${ }^{8}$ A positive association is found between daily death counts of COVID-19 and DTR. Absolute humidity is negatively associated with daily death counts of COVID-19. ${ }^{8}$ India is four times more populous than the US, but has just $2 \%$ the number of cases and only $1.5 \%$ of the number of COVID-19 deaths. How has the country, whose per capita income is just tenth of the US, avoided being flattened by the pandemic? From the date of Table 1, also it's very clear that as on 08 June 2020 also the death rate is lowest in India as compared to other countries. ${ }^{9}$

So why is fate apparently smiling on us? Why has India been fortunate so far? ${ }^{10}$

The virus (infective agent) is COVID-19 (also called SARS-CoV-2). Past experience indicates that such viruses undergo rapid mutation and several variants are generally circulated in different geographical regions. At least two strains have been reported from China. ${ }^{11}$

If the lower mortality in India (and Asian countries in general) is really true, could it be because of differences in adaptive immunity between developing countries and the Western world?

Authors have earlier suggested that viral RNA associated with malaria plasmodium may have sensitized the immune system in people living in malaria endemic areas. ${ }^{12}$ This may have conferred protection due to preexisting immunity, which protects significant number of people in countries like India from serious consequences of COVID-19 exposure.
Indians are exposed to infective antigens early in life. Potential benefits of such exposure, as published in the past, include better gut microbiota, less autoimmune diseases, and lower incidence of pediatric acute lymphoblastic leukemia. ${ }^{13}$

It has also been reported that Indians have larger number of NK cells which help in fighting infections quickly. ${ }^{14} \mathrm{~A}$ study is ongoing to document the effect of BCG vaccination in mitigating the effect of COVID-19 exposure. ${ }^{15}$ This study is based some evidence that suggests the potential benefit of the BCG vaccine - which is given to all Indians at birth. This could also serve to protect Indians through the $\mathrm{T}$ cell-mediated immunity pathway.

The environment is highly variable across the vast expanse of India. At one end, we have hot deserts where the summer temperature can be as high as $50^{\circ} \mathrm{C}$ and at the other end of the spectrum is Drass which recorded the second lowest temperature of any inhabited place on earth at $-40^{\circ} \mathrm{C}{ }^{16}$

The "Global Virus Network" says that COVID-19 requires a temperature range of $5-11^{\circ} \mathrm{C}$ to propagate. ${ }^{17}$ If this is true, the ambient temperature in most parts of our country should be sufficient to counter the pandemic and result in lower incidence of infections and deaths due to the ongoing pandemic. Only time will tell, whether the above factors are sufficiently strong to protect the majority of Indians during the ongoing COVID-19 pandemic.

To conclude, It can be said that In India Climate, with temperature, humidity, BCG vaccination, immune status of persons, elderly people, uncontrolled co morbid conditions like heart diseases, DM, hypertension, kidney diseases seems to play an important role in reducing severity of corona virus infection. ${ }^{1}$ There will be lot of infections and cases. A lot of cases which will help in building herd immunity. But the mortality rate will be definitely less as it seems that the virus may not manifest its severity in hot and humid climate like India and there may be some other factors also. The death rates will be more in uncontrolled co morbid conditions like 
cardiovascular disease, diabetes, chronic respiratory disease, and cancer. Particularly older people will suffer more. So, the best strategy will be to selectively isolate and selectively quarantine people above 50 years of age with co morbidity. Precautions of hand washing, using a mask whenever required and social distancing ( 2 meters distance) should be followed. Definitely we can live with corona just like swine flu. This has to be done till we get a good vaccine or effective treatment. Definitely we can live with corona just like swine flu. Lock down should be lifted in gradual manner with all precautions of preventing COVID-19 in order to boost economic growth which is also badly needed.

\section{REFERENCES}

1. Yao Y, Pan J, Liu Z, Meng X, Wang W, Kan H, et al. No Association of COVID-19 transmission with temperature or UV radiation in Chinese cities. Eur Respir J. 2020;55(5):2000517.

2. Health Advisory for Elderly Population of India during COVID19. Available at: https://www. mohfw.gov.in/pdf/AdvisoryforElderlyPopulation.pd f. Accessed on 3 March 2020.

3. Tan J, Mu L, Huang J, Yu S, Chen B, Yin J. An initial investigation of the association between the SARS outbreak and weather: with the view of the environmental temperature and its variation. J Epidemiol Community Health. 2005;59(3):186-92.

4. WHO, W. H. O. Coronavirus disease (COVID2019) situation reports. Available at: https://www. who.int/docs/default-source/coronaviruse/situationreports/20200227-sitrep-38-covid19.pdf?sfvrsn $=9 f 98940 \mathrm{c}$. Accessed on 3 March 2020 .

5. $\mathrm{Xu} \mathrm{Z,} \mathrm{Hu} \mathrm{W,} \mathrm{Williams} \mathrm{G,} \mathrm{Clements} \mathrm{AC,} \mathrm{Kan} \mathrm{H,}$ Tong S. Air pollution, temperature and pediatric influenza in Brisbane, Australia. Environ Int 2013, 59, 384-8.

6. Puleo M. AccuWeather staff writer, New study says 'high temperature and high relative humidity significantly reduce' spread of COVID-19. Available

https://www.accuweather.com/en/health-

wellness/new-study-says-high-temperature-andhigh-relative-humidity-significantly-reduce-spreadof-covid-19/703418. Accessed on 21 March 2020.
7. Malani A, Gupta A, Abraham R. Why does India have so few Covid-19 cases and deaths? QUARTZ India, 2020.

8. Wang J, Tang K, Feng K, Weifeng. High Temperature and High Humidity Reduce the Transmission of COVID-19. Quantitative Biol Populations Evol. 2003:05003.

9. WHO, CDC, ECDC, NHC of the PRC, JHU CSSE, DXY, QQ, and various international media as on 8/6/2020. Available at: Coronatracker.com. Accessed on 08 June 2020.

10. Available at: https://www.timesofindia.indiatimes.com/life-style/health-fitness/health-news/isthe-indian-covid-19-strain-weaker/articleshow/74823660.cms. Accessed on 28 March 2020.

11. Available at: https://www.academic.oup.com/ nsr/advance-article/doi/10.1093/nsr/nwaa036/5775463. Accessed on 28 March 2020.

12. Mehta P, Parikh PM, Aggarwal S, Batra A, Patel A,. Impact of region specific factors on dynamics of SARS-CoV2 infection: A perspective. Indian J Med Sci. 2020.

13. Marcotte EL, Ritz B, Cockburn M, Yu F, Heck JE. Exposure to infections and risk of leukemia in young children. Cancer Epidemiol Biomarkers Prev. 2014;23:1195-203.

14. Parikh P, Mehta P, Kumar P, Gulia A. Why are Indians having lower incidence of infections and deaths due to the COVID-19 virus? Indian J Med Sci. 2020;71(3):102-3.

15. Available at: https://www.clinicaltrialsarena. com/news/australia-bcg-vaccine-trial-covid-19. Accessed on 28 March 2020.

16. Available at: https://www.economictimes.indiatimes.com/magazines/panache/summer-in-drassindias-coldest-inhabited-place/articleshow/64141 398.cms?from=mdr. Accessed on 28 March 2020.

17. Available at: https://www.gvn.org/enhanced-modelfor-monitoring-zones-of-increased-risk-of-covid-19spread. Accessed on 28 March 2020.

Cite this article as: Vasantrao CS. Why there are and will be less deaths in India due to COVID-19: an insight. Int J Community Med Public Health 2020;7:3301-3. 